\title{
Regulation of lipid metabolism-related gene expression in whole blood cells of normo- and dyslipidemic men after fish oil supplementation
}

\author{
Simone Schmidt ${ }^{1}$, Janina Willers ${ }^{1}$, Frank Stahl' ${ }^{2}$, Kai-Oliver Mutz ${ }^{2}$, Thomas Scheper ${ }^{2}$, Andreas Hahn ${ }^{1+}$ \\ and Jan Philipp Schuchardt ${ }^{{ }^{*}+}$
}

\begin{abstract}
Background: Beneficial effects of omega-3 polyunsaturated fatty acids (n-3 PUFAs) on the lipid levels of dyslipidemic subjects are widely described in the literature. However, the underlying molecular mechanisms are largely unknown. The aim of this study was to investigate the effects of n-3 PUFAs on the expression of lipid metabolism-related genes in normo- and dyslipidemic men to unveil potential genes and pathways affecting lipid metabolism.

Methods: Ten normo- and ten dyslipidemic men were supplemented for twelve weeks with six fish oil capsules per day, providing $1.14 \mathrm{~g}$ docosahexaenoic acid and $1.56 \mathrm{~g}$ eicosapentaenoic acid. The gene expression levels were determined by whole genome microarray analysis and quantitative real-time polymerase chain reaction.

Results: Several transcription factors (peroxisome proliferator-activated receptor a (PPARa), retinoid $X$ receptor (RXR) a, RXRY, hepatic nuclear factor (HNF) 6, and HNF1ß) as well as other genes related to triacylglycerol (TG) synthesis or high-density lipoprotein (HDL-C) and cholesterol metabolism (phospholipids transfer protein, ATP-binding cassette sub-family G member 5, 2-acylglycerol O-acyltransferase (MOGAT) 3, MOGAT2, diacylglycerol O-acyltransferase 1, sterol O-acyltransferase 1, apolipoprotein CII, and low-density lipoprotein receptor) were regulated after n-3 PUFA supplementation, especially in dyslipidemic men.
\end{abstract}

Conclusion: Gene expression analyses revealed several possible molecular pathways by which n-3 PUFAs lower the TG level and increase the HDL-C and low-density lipoprotein level, whereupon the regulation of PPARa appear to play a central role.

Trial registration: ClinicalTrials.gov (ID: NCT01089231)

Keywords: Omega-3 fatty acids, TG lowering, Dyslipidemia, PPARa, HNF, RXR

\section{Background}

Fish oil (FO) and its principal omega-3 polyunsaturated fatty acids (n-3 PUFAs), eicosapentaenoic acid (EPA, 20:5n-3) and docosahexaenoic acid (DHA, 22:6n-3), have shown beneficial effects on the lipid profile in numerous interventional studies [1-3]. Primarily, n-3 PUFAs lower triacylglycerol (TG) levels, especially in subjects with

\footnotetext{
* Correspondence: Schuchardt@nutrition.uni-hannover.de

${ }^{\dagger}$ Equal contributors

'Institute of Food Science and Human Nutrition, Faculty of Natural Sciences at the Leibniz University of Hannover, Am Kleinen Felde 30, Hannover 30167, Germany

Full list of author information is available at the end of the article
}

hypertriglyceridemia [4-6]. The TG-lowering effect of $n$ 3 PUFAs is more pronounced at higher baseline TG levels [3] and appears to be dose-dependent $[1,3]$. The recommended daily intake of $n-3$ PUFAs for TG lowering in hypertriglyceridemic subjects ranges from 2 to $5 \mathrm{~g} / \mathrm{d}$; amounts which could only be reached by supplementation $[7,8]$. However, moderate $\mathrm{n}-3$ PUFA doses $(1.68 \mathrm{~g} / \mathrm{d})$ are similarly efficient at reducing elevated TG levels in subjects with mild hypertriglyceridemia [9].

Numerous mechanisms have been proposed as contributors to the TG-lowering effect of n-3 PUFAs, for example, by reducing very low-density lipoprotein(VLDL) TG synthesis and secretion from the liver, or

\section{Biomed Central}


by enhancing the TG clearance of circulating VLDL and chylomicron particles [10]. Beyond TG lowering, n-3 PUFAs additionally affect the high-density lipoprotein cholesterol (HDL-C) metabolism by elevating the cholesterol-rich HDL2 subtype and reducing the TGrich HDL3 subtype [11,12]. Beside these beneficial effects, studies have repeatedly shown that n-3 PUFAs increase low-density lipoprotein cholesterol (LDL-C) levels, which may result from the conversion of VLDL to LDL-C [13].

The molecular mechanisms by which n-3 PUFAs modify the lipid metabolism are not completely clarified. The regulation of gene expression is believed to be a key mechanism of how n-3 PUFAs mediate their functions. Specifically, n-3 PUFAs can modulate the activity of several transcription factors, such as sterol regulatory element-binding protein (SREBP) 1 [14], hepatic nuclear factor (HNF) $4 \alpha$ [15], liver X receptors [16], retinoid X receptor (RXR) [17], farnesoid X receptor [18], and peroxisome proliferator-activated receptors (PPARs) [19], resulting in an altered expression of corresponding target genes [20-24]. Although it is known that these genes, or rather their products, play eminent roles in the regulation of the lipid metabolism, the influence of $n-3$ PUFAs on a number of additional lipid metabolismrelated genes and involved pathways remain to be discovered. Unravelling these connections may contribute to the understanding of the molecular mechanisms explaining the physiological functions of $n-3$ PUFAs.

The approach of this interventional trial was to monitor gene expression changes in normo- and dyslipidemic male subjects after n-3 PUFA supplementation using whole blood samples. With a focus on lipid metabolismrelated genes, we aimed to not only identify genes and associated pathways that confirm already known mechanisms, but also to point out alternative mechanisms of how n-3 PUFAs affect lipid metabolism.

\section{Methods}

This controlled, parallel group intervention study was conducted at the Institute of Food Science and Human Nutrition, Leibniz University of Hannover, Germany, and performed with respect to GCP (Good Clinical Practice) Guidelines. The approval of the Freiburg Ethics Commission International (FECI) was received. The clinical investigation was registered at ClinicalTrials.gov with the identification number NCT01089231.

Parts of this study have been published recently. In two other publications, we presented regulated pathways, which have been discovered in normo- and dyslipidemic male subjects after FO supplementation [25] as well as regulated antioxidative genes expression [26]. Therefore, selection criteria for the study subjects, the study design as well as the sample collection for gene expression analyses and methodical procedure of microarray experiments are described elsewhere [26].

\section{Determination of fasting serum lipids and apolipoprotein B48 concentration}

Fasting venous blood samples were collected into BD Vacutainer ${ }^{\circledR}$ Blood Collection Tubes (Becton Dickinson, Heidelberg, Germany) at baseline $\left(\mathrm{t}_{0}\right)$ and after twelve weeks $\left(t_{12}\right)$ of supplementation. The plasma lipid levels were determined by specific enzymatic colour reactions from an external contract laboratory (LADR, Hannover, Germany).

Apolipoprotein (Apo) B48 concentration in fasting serum at baseline and after twelve weeks was determined in 12 subjects using the Shibayagi human Apo B48 enzyme linked immunosorbent assay (ELISA) kit (Xceltis GmbH, Mannheim, Germany). Analysis was performed in accordance to the manufacturer's recommended procedures.

\section{Quantitative real-time polymerase chain reaction (qRT- PCR) and data analysis}

In order to quantify the expression levels of selected genes, equal amounts of cDNA were synthesized using $2.0 \mu \mathrm{g}$ of purified RNA and M-MLV reverse transcriptase (Promega, Mannheim, Germany), as well as random hexamer (Fermentas, St. Leon-Rot, Germany) and oligo (dT) primers (Carl Roth, Karlsruhe, Germany). Synthesized cDNA was diluted 1:20 with nuclease-free water and used for the qRT-PCR together with iQ SYBR Green Supermix (Bio-Rad Laboratories, Hercules, Ca, USA) and $5 \mathrm{pmol}$ of both forward and reverse primers. The sequences for target and reference genes were retrieved from GenBank and the primers applied were manually designed with the Primer-BLAST tool of the National Centre for Biotechnology Information, which is based on the program Primer3 [27]. The primer sequences used are listed in Table 1. Glyceraldehyde-3-phosphate dehydrogenase (GAPDH) and ribosomal protein S2 (RPS2) were identified as the most stable reference genes by the freely available algorithm geNorm version 3.5.

\section{Statistics}

Statistical analysis of blood lipids was processed with SPSS software version 17.0 (SPSS Inc., Chicago, IL, USA). Statistical analyses were based on per protocol population, defined as subjects completing all visits not infringing the study protocol. The results are presented as mean \pm SD (Table 2). Statistical analysis of Apo B48 levels was performed with the statistical package $\mathrm{R}$ version 2.15.0. Differences between $t_{0}$ and $t_{12}$ were tested within groups by paired $t$-test and differences between groups were examined by $t$-test. P-values $\leq 0.05$ were interpreted as statistically significant. 
Table 1 Nucleotide sequences of primers for quantitative real-time polymerase chain reaction

\begin{tabular}{|c|c|c|c|c|}
\hline & Gene symbol & RefSeq_ID & Sequenc & \\
\hline \multirow[t]{2}{*}{ Target genes } & Apo C II & NM_000483.3 & $\begin{array}{l}\text { forward } \\
\text { reverse }\end{array}$ & $\begin{array}{l}\text { GCTCCCCCTTCCCAGTAGCTCT } \\
\text { TTCACTGCTTTATTCCCATGGACCC }\end{array}$ \\
\hline & LDLR & NM_000527.3 & $\begin{array}{l}\text { forward } \\
\text { reverse }\end{array}$ & $\begin{array}{l}\text { GGGGCCCTGTGTAGGGGGTT } \\
\text { AAAGTGACACCCATCTCCCAGAAGC }\end{array}$ \\
\hline \multirow[t]{2}{*}{ Reference genes } & GAPDH & NM_002046.3 & $\begin{array}{l}\text { forward } \\
\text { reverse }\end{array}$ & $\begin{array}{l}\text { AAGGTGGTGAAGCAGGCGTCG } \\
\text { AATGCCAGCCCCAGCGTCAAAG }\end{array}$ \\
\hline & RPS2 & NM_002952.3 & $\begin{array}{l}\text { forward } \\
\text { reverse }\end{array}$ & $\begin{array}{l}\text { GCAACTTCGCCAAGGCCACCTT } \\
\text { TGGGTCTTGACGAGGTGGTCAGT }\end{array}$ \\
\hline
\end{tabular}

Statistical analysis of the expression ratios of genes, which were quantified by qRT-PCR, were calculated with the Gene Expression Macro tool (Bio-Rad), which is based on the algorithm of geNorm [28]. Firstly, normalization factors were calculated from the geometric mean of the reference genes GAPDH and RPS2. Furthermore, the baseline values of the normolipidemic group were defined as control values so that relative expression values could be calculated. Therefore, the baseline samples of the normolipidemic group are given a value of 1 .

\section{Results}

\section{Subject characteristics}

All subjects completed the study. One normo- and three dyslipidemic subjects had to be excluded from the analyses because of low RNA yield $(\mathrm{n}=3)$ and consumption of medication that led to exclusion $(n=1)$. Thus, data were available from nine normolipidemic and seven dyslipidemic subjects for each investigation time point.

Age and mean weight at baseline did not show any differences between either group. However, the dyslipidemic subjects had a significantly higher BMI than the normolipidemic subjects $\left(28.13 \mathrm{~kg} / \mathrm{m}^{2}\right.$ vs. $23.66 \mathrm{~kg} / \mathrm{m}^{2}$, respectively). Subjects of the dyslipidemic group can be characterised as pre-obese (BMI 25-30), which is, among others, an underlying cause for dyslipidemia. Nevertheless, the BMI was not changed by dietary intervention in either of the study groups.

\section{Changes of blood lipids and apolipoprotein B48 levels}

According to the inclusion criteria, dyslipidemic subjects had significantly higher TC and TG levels as well as a higher LDL-C/HDL-C ratio at baseline (Table 2). After twelve weeks of supplementation with FO, the group differences in TC and TG levels and the LDL-C/ HDL-C ratio remained unaffected and similar to differences observed at baseline. TG levels decreased both in normolipidemic $(-19.2 \mathrm{mg} / \mathrm{dl} ;-23.34 \%)$ and dyslipidemic subjects $(-99.86 \mathrm{mg} / \mathrm{dl},-27.59 \%)$. The difference between both groups was not statistically significant. The LDL-C level increased significantly after FO supplementation in dyslipidemic subjects $(29.6 \mathrm{mg} / \mathrm{dl}$; $20.19 \%)$, whereas the effect in normolipidemic subjects was marginal $(4.0 \mathrm{mg} / \mathrm{dl} ; 3.69 \%)$. Furthermore, FO supplementation resulted in a significant increase in the HDL-C levels in dyslipidemic subjects $(6.28 \mathrm{mg} / \mathrm{dl}$; $13.69 \%)$, whereas the HDL-C increase in normolipidemic subjects $(7.0 \mathrm{mg} / \mathrm{dl} ; 11.93 \%)$ showed a tendency towards statistical significance.

The protein level of Apo B48 in dyslipidemic subjects at baseline was six times higher compared to normolipidemic subjects $(\mathrm{p}=0.053) \quad$ (Figure 1). After twelve weeks of FO supplementation, Apo B48 levels decreased both in normolipidemic $(-1.8 \mu \mathrm{g} / \mathrm{ml} ;-36 \%)$ and dyslipidemic subjects $(-32.6 \mu \mathrm{g} / \mathrm{ml} ;-33 \%)$, but only the decrease of the dyslipidemic subjects showed a tendency of significance $(p=0.059)$.

Table 2 Serum lipid levels of the normo- and dyslipidemic men at baseline $\left(t_{0}\right)$ and after supplementation with fish oil over twelve weeks $\left(t_{12}\right)$

\begin{tabular}{|c|c|c|c|c|}
\hline \multirow[t]{2}{*}{ Parameters } & \multicolumn{2}{|c|}{ Normolipidemic $(n=9)$} & \multicolumn{2}{|c|}{ Dyslipidemic $(n=7)$} \\
\hline & $t_{0}$ & $t_{12}$ & $t_{0}$ & $t_{12}$ \\
\hline Total cholesterol [mg/dl] & $183.33 \pm 13.88^{a}$ & $190.56 \pm 21.88^{b}$ & $272.86 \pm 67.17^{a}$ & $278.40 \pm 45.21^{b}$ \\
\hline Triacylglycerol [mg/dl] & $82.22 \pm 37.42^{a}$ & $63.00 \pm 14.09^{b}$ & $362.00 \pm 284.62^{a}$ & $262.14 \pm 153.52^{b}$ \\
\hline High-density lipoprotein [mg/dl] & $58.67 \pm 10.92$ & $65.67 \pm 15.23^{c_{-} \top}$ & $45.86 \pm 6.15$ & $52.14 \pm 9.84^{c}$ \\
\hline Low-density lipoprotein [mg/dl] & $108.33 \pm 13.54$ & $112.33 \pm 16.88^{b}$ & $146.60 \pm 6.43$ & $176.20 \pm 20.56^{b c}$ \\
\hline LDL-C/HDL-C quotient & $1.90 \pm 0.37^{a}$ & $1.80 \pm 0.51^{b}$ & $3.10 \pm 0.47^{a}$ & $3.28 \pm 0.89^{b}$ \\
\hline
\end{tabular}

a: $p<0.05$ (Changes of means at baseline were evaluated between normolipidemic and dyslipidemic subjects by Student's $t$-test).

b: $p<0.05$ (Changes of means after twelve weeks of supplementation were evaluated between normolipidemic and dyslipidemic subjects by Student's $t$-test). $c: p<0.05$ (Changes between $t_{0}$ and $t_{12}$ were evaluated within groups by Student's $t$-test for dependent samples).

_ $\mathrm{T}: \mathrm{p}<0.1$ (trend of significance). 


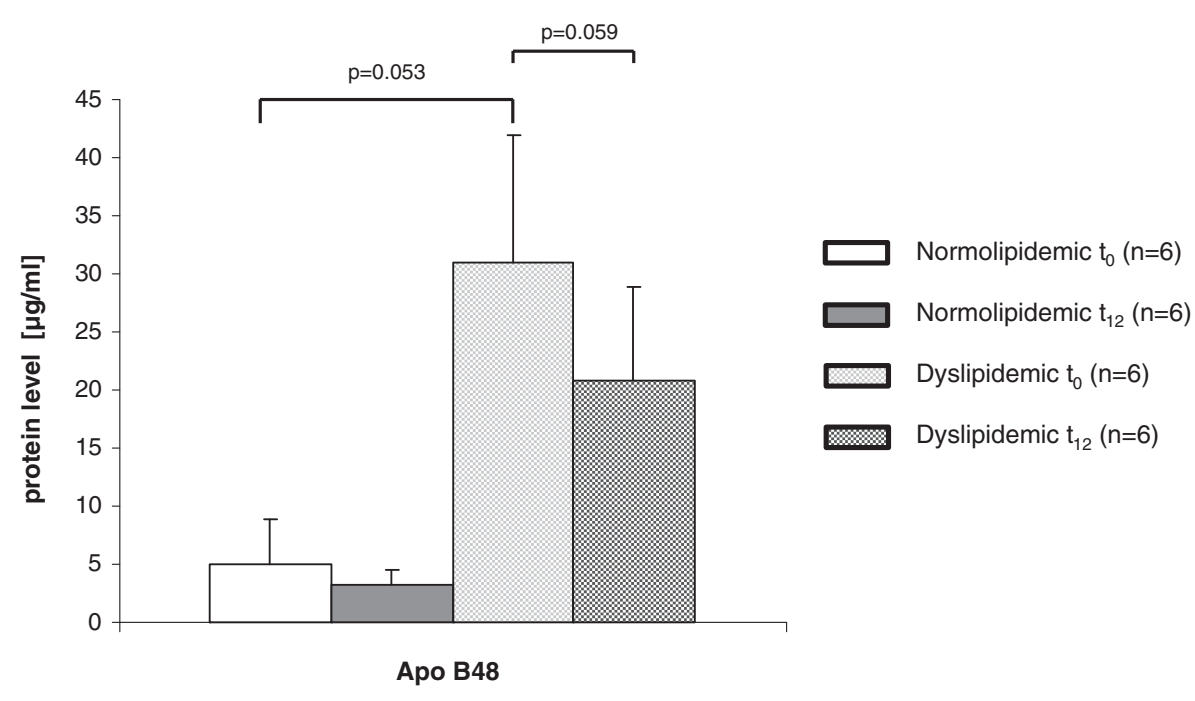

Figure 1 Protein levels of apolipoprotein B48 in normolipidemic and dyslipidemic men. Serum protein levels of apolipoprotein B48 (Apo B48) was determined by ELISA in normo- and dyslipidemic men before $\left(t_{0}\right)$ and after twelve weeks $\left(t_{12}\right)$ of fish oil supplementation. Differences between $t_{0}$ and $t_{12}$ protein levels were tested by a paired $t$-test, and differences between groups at each time point were tested by unpaired t-test using the statistical package $\mathrm{R}$ version 2.15.0.

\section{Gene expression changes of lipid metabolism-related genes after $n-3$ PUFA supplementation}

Microarray experiments revealed a transcriptional regulation of several transcription factors after FO supplementation, including PPAR alpha (PPAR $\alpha)$, RXR alpha (RXR $\alpha$ ), RXR gamma (RXRY), HNF6, and HNF1ß (Table 3). While some transcription factors were similarly regulated in normolipidemic men, the expression was distinctly more strongly regulated in dyslipidemic men. Additionally, several genes related to TG synthesis and HDL-C and cholesterol metabolism were regulated in dyslipidemic men (Table 3). More precisely, the PPAR target gene phospholipid transfer protein (PLTP), as well as the ATP-binding cassette sub-family G member 5 (ABCG5) were up-regulated, while 2acylglycerol O-acyltransferase 3 (MOGAT3), MOGAT2, diacylglycerol O-acyltransferase 1 (DGAT1), and sterol O-acyltransferase 1 (SOAT1) were down-regulated after FO supplementation in dyslipidemic men.

Gene expression changes of Apo CII and LDL receptor (LDLR) were quantified by qRT-PCR (Figure 2). The expression of Apo CII in dyslipidemic subjects at baseline was three times higher compared to normolipidemic subjects $(p=0.05)$. After twelve weeks of FO supplementation, the expression of Apo CII was slightly up-regulated in normolipidemic subjects, and significantly down-regulated in dyslipidemic subjects $(-57.2 \% ; \mathrm{p}=0.04)$. The expression of LDLR in normolipidemic subjects at baseline was twice as high compared to dyslipidemic subjects $(\mathrm{p}=0.008)$. After twelve weeks of FO supplementation, no changes in LDLR expression were observed in normolipidemic subjects, while dyslipidemic subjects showed a significant downregulation in LDLR expression $(\mathrm{p}=0.02)$.

\section{Discussion}

The effects of n-3 PUFAs on lipid levels in dyslipidemic conditions are well-known, however, only a few human studies investigated the underlying molecular mechanisms of gene expression levels in humans. Therefore, we performed a twelve-week lasting n-3 PUFA supplementation trial with normo- and dyslipidemic male subjects aiming to identify possible molecular pathways of n-3 PUFAs in humans.

Parts of this study have been published recently, presenting regulated pathways of the lipid metabolism after FO supplementation such as fatty acid biosynthesis, fatty acid elongation in mitochondria, fatty acid metabolism, glycerolipid metabolism, glycerophospholipid metabolism, arachidonic acid metabolism, linoleic acid metabolism and alpha-linoleic acid metabolism [25]. The present paper focuses on the influence of n-3 PUFAs on specific lipid metabolism associated gene expression.

Although the lipid metabolism is mainly located in the liver, several key regulators of the TG, HDL-C and LDL$\mathrm{C}$ metabolism were found to be regulated on a transcriptional level in whole blood cells.

\section{TG metabolism}

Supplementation of normo- and dyslipidemic subjects with n-3 PUFAs resulted in a decrease of TG levels by 23 and $28 \%$, which is comparable to other studies [10]. Several genes which are likely to be involved in TG lowering were observed to be regulated (Figure 2). 
Table 3 Expression ratios of lipid metabolism-related genes

\begin{tabular}{|c|c|c|c|c|c|c|c|c|c|c|}
\hline \multirow[t]{3}{*}{ Gene } & \multirow{3}{*}{$\begin{array}{l}\text { Gene } \\
\text { symbol }\end{array}$} & \multirow[t]{3}{*}{ Entrez_ID } & \multirow[t]{3}{*}{ RefSeq_ID } & \multicolumn{3}{|c|}{ dyslipidemic } & \multicolumn{3}{|c|}{ normolipidemic } & \multirow[t]{3}{*}{ Function } \\
\hline & & & & Ratio & Ratio & Ratio & Ratio & Ratio & Ratio & \\
\hline & & & & $t_{4 h}: t_{0}$ & $t_{1}: t_{0}$ & $t_{12}: t_{0}$ & $t_{4 h}: t_{0}$ & $t_{1}: t_{0}$ & $t_{12}: t_{0}$ & \\
\hline \multicolumn{11}{|l|}{ Transcription factors } \\
\hline $\begin{array}{l}\text { Peroxisome proliferator-activated } \\
\text { receptor alpha }\end{array}$ & PPARA & 5465 & $\begin{array}{l}\text { NM_001001928.2 } \\
\text { NM_005036.4 }\end{array}$ & $-8.19^{*}$ & $2.72^{* *}$ & - & - & - & - & \multirow{5}{*}{$\begin{array}{l}\text { Regulation of the } \\
\text { lipid metabolism }\end{array}$} \\
\hline Retinoic X receptor RXR-alpha & RXRA & 6256 & NM_002957.4 & - & $-4.50^{*}$ & - & $3.14^{*}$ & $3.79^{*}$ & & \\
\hline Retinoic acid receptor RXR-gamma & RXRG & 6258 & NM_006917.3 & $3.16^{* * *}$ & $4.79^{* * *}$ & $4.11^{* * *}$ & $-3.19^{* *}$ & - & $-2.03^{* *}$ & \\
\hline Hepatocyte nuclear factor 6 & HNF6 & 3175 & NM_004498.1 & $-2.27^{*}$ & $-4.89^{*}$ & $-3.43^{*}$ & - & - & - & \\
\hline Hepatocyte nuclear factor 1-beta & HNF1B & 6928 & NM_000458.2 & - & $-3.64^{*}$ & $-2.56^{*}$ & - & - & - & \\
\hline \multicolumn{11}{|l|}{ Triacylglycerol synthesis } \\
\hline 2-acylglycerol O-acyltransferase 3 & MOGAT3 & 346606 & NM_178176.2 & - & $-27.07^{*}$ & $-3.48^{*}$ & - & - & - & \multirow{3}{*}{ TG synthesis } \\
\hline 2-acylglycerol O-acyltransferase 2 & MOGAT2 & 80168 & NM_025098.2 & $-3.08^{*}$ & - & - & - & - & - & \\
\hline Diacylglycerol O-acyltransferase 1 & DGAT1 & 8694 & NM_012079.4 & - & $-2.67^{*}$ & - & - & - & - & \\
\hline \multicolumn{11}{|l|}{ HDL-C metabolism } \\
\hline Phospholipid transfer protein & PLTP & 5360 & $\begin{array}{l}\text { NM_006227.2 } \\
\text { NM_182676.1 }\end{array}$ & - & $3.30^{*}$ & $4.15^{*}$ & - & - & - & $\begin{array}{l}\text { Modify HDL-C } \\
\text { particles size }\end{array}$ \\
\hline \multicolumn{11}{|l|}{ Cholesterol metabolism } \\
\hline $\begin{array}{l}\text { ATP-binding cassette sub-family } G \\
\text { member } 5\end{array}$ & ABCG5 & 64240 & NM_022436.2 & - & $4.06^{*}$ & $5.34^{*}$ & - & - & - & Cholesterol efflux \\
\hline sterol O-acyltransferase 1 & SOAT1 & 6646 & NM_003101.4 & - & $-2.45^{*}$ & $-2.37^{* *}$ & - & - & - & $\begin{array}{l}\text { Cholesterol } \\
\text { synthesis }\end{array}$ \\
\hline
\end{tabular}

Expression ratios were displayed for genes which were differentially expressed after four hours $\left(t_{4 h}\right)$, one week $\left(t_{1}\right)$ and twelve weeks $\left(t_{12}\right)$ of fish oil supplementation in normolipidemic and dyslipidemic men.

-: no regulation.

$: p=0.05$.

$: p<0.05$

${ }^{* * *}: p<0.01$.

Consistent with findings from other studies $[29,30]$, PPAR $\alpha$ was up-regulated in dyslipidemic men after one week of n-3 PUFA supplementation. Transactivation of PPARs results in a repression of Apo CIII and Apo B, which, in turn, results in an enhanced lipoprotein lipase
(LPL)-mediated catabolism of VLDL and reduced VLDL production [31]. Currently, this metabolic pathway is believed to be the main mechanism by which n-3 PUFAs reduce TG levels [10]. Expression changes of genes coding for Apo CIII and Apo B were not observed in this

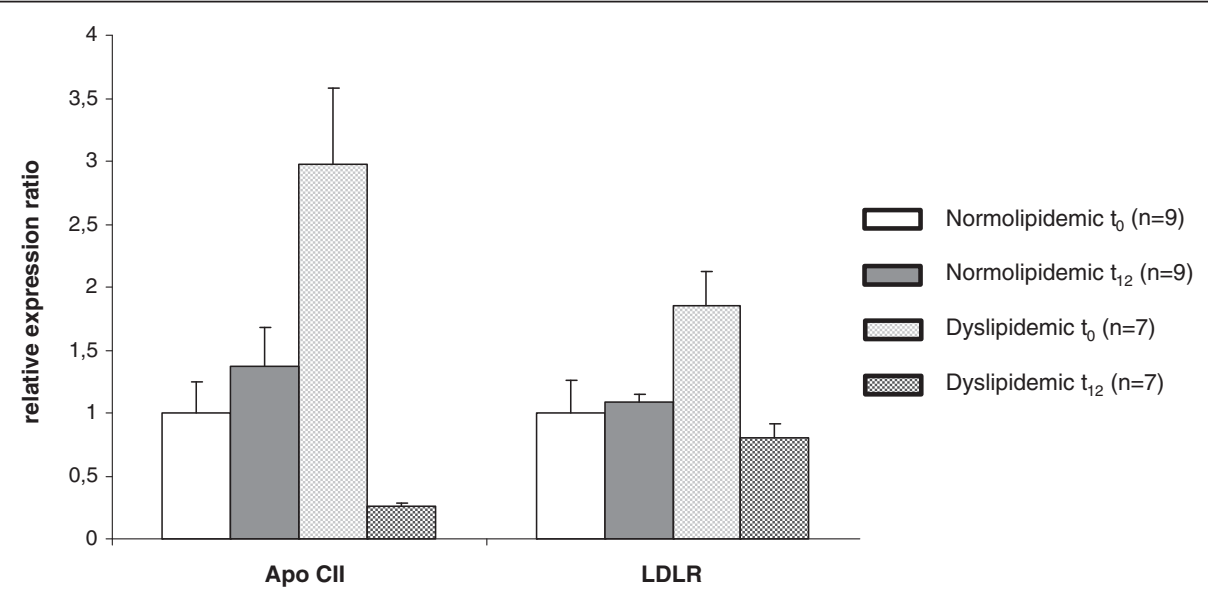

Figure 2 Regulatory effects of eicosapentaenoic acid and docosahexaenoic acid on lipid metabolism related genes. The Figure presented is based on the analysis of gene expression changes after fish oil supplementation in dyslipidemic male subjects. While bold text and black and grey arrows present findings discovered in this thesis, grey arrows symbolize that until now it has not been clarified if genes are target genes of PPARa. In addition, broken arrows symbolize further possible mechanisms of action based on findings from the literature. 
study, possibly because these factors are not expressed in blood cells but in other organs and tissues [32-34].

Two other transcription factors besides PPAR $\alpha$ were regulated after n-3 PUFA supplementation. HNF6 and HNF1ß were down-regulated in dyslipidemic subjects at nearly all time-points. HNF6 is associated with several regulatory pathways influencing glucose metabolism, cholesterol metabolism, bile acid biosynthesis, as well as the synthesis and transport of serum carrier proteins [35]. Synergisms between HNF6 and HNF1 $\alpha$ or between HNF1 $\beta$ and GATA6 could increase the activity of the HNF4 $\alpha$ promoter [36], which, in turn, increases VLDL secretion. Since Apo CIII and Apo B are target genes of HNF4 $\alpha$ [37], a reduced HNF4 $\alpha$ expression, mediated by a down-regulation of HNF6 and HNF1ß, may reduce the VLDL secretion; the main TG-lowering effect of $n-3$ PUFAs. However, expression changes of HNF4 $\alpha$ were not observed after FO supplementation in our experiments, most likely because HNF4 $\alpha$ is expressed in liver, kidney, intestine, and pancreas [38]. Nevertheless, a robust suppression of the transcriptional HNF4 $\alpha$ activity by $\mathrm{n}-3$ PUFAs has been shown in vitro [39]. Furthermore, it was found that n-3 PUFAs reduce the expression of $H N F 4 \alpha$ in rat hepatocytes resulting in a decreased expression of Apo B and microsomal TG transfer protein, which suggests a reduced VLDL secretion [15]. Taken together, these findings suggest that this molecular pathway is a possible mechanism explaining the TG-lowering effect of n-3 PUFAs.

In addition to transcription factors, the expression of several other TG metabolism-associated genes was regulated after n-3 PUFA supplementation. Apo CII acts as a cofactor for LPL, which hydrolyses TGs in chylomicrons and VLDL particles to glycerine and free FAs. Therefore, constant Apo CII levels are crucial for LPL activation [40], ensuring efficient lipolysis of TGrich lipoproteins. Studies have shown that dyslipidemic subjects without genetic disorders present higher Apo CII levels $(7.0 \mathrm{mg} / \mathrm{dl})$ than normolipidemic subjects $(3.0 \mathrm{mg} / \mathrm{dl})[41,42]$, which results in a disturbance of the Apo CII/LPL balance. Dyslipidemic subjects of our study consistently exhibited higher Apo CII mRNA expression levels than normolipidemic subjects at baseline. After FO treatment, Apo CII expression was down-regulated in dyslipidemic men suggesting a re-establishment of the Apo CII/LPL balance and an increased LPL-mediated TG clearance. In agreement, Zhang and co-workers [43] observed reduced plasma Apo CII levels in Chinese woman after increased fish intake $(80 \mathrm{~g}$ fatty fish five times per week) over eight weeks.

Finally, the mRNA expression of three genes involved in TG synthesis, MOGAT3, MOGAT2 and DGAT1, were down-regulated in dyslipidemic men after n-3 PUFA supplementation. MOGATs and DGATs are key enzymes of the monoacylglycerol (MAG) pathway [44], which is primarily responsible for the re-synthesis of TGs from FAs and 2-MAG in enterocytes [45-47]. Besides the intestine, MOGAT2 and MOGAT3 are similarly expressed in the liver [44,47], whereas DGAT1 is expressed ubiquitously [48]. To the best of our knowledge, an effect of n-3 PUFAs on the expression of MOGAT2 and MOGAT3 has not yet been described. Knockdown of MOGAT3 by siRNA in liver-derived cells was followed by a reduced enzyme activity [44], which is accompanied by reduced intestinal dietary fat absorption in mice [49]. Due to their involvement in TG resynthesis and secretion, it is believed that MOGAT2 and 3, but also DGAT1 are potential therapeutic drug targets for treating diet-induced dyslipidemia and obesity [44,49-51], whereas an activation of PPAR $\alpha$ was suggested as the initial regulator [52]. We assume that the down-regulation of MOGAT2, MOGAT3 and DGAT1, observed in whole blood cells after FO supplementation, will similarly take place in enterocytes or hepatocytes, resulting in a reduced re-synthesis of TG and thus TG levels in circulation.

In addition, n-3 PUFA supplementation resulted in a marked reduction of Apo B48 levels ( 30\%), which might support this hypothesis. Apo B48 is an integral stabilizing component of re-synthesized TG containing chylomicrons [53]. Patients with hyperlipidemia and metabolic syndrome show elevated Apo B48 levels compared to normolipidemic subjects $[54,55]$, which is connected with a higher cardiovascular risk. A reduced re-synthesis and secretion of TG in enterocytes would be accompanied with a reduced formation of chylomicrons and associated Apo B48. The lowering effect of n-3 PUFAs on levels of chylomicrons, their remnants, as well as Apo B48 has been shown in other studies [8]. However, beside this indirect effect, n-3 PUFAs might directly influence the synthesis of Apo B48.

\section{HDL cholesterol metabolism}

As expected, FO supplementation increased HDL-C levels in both normo- and dyslipidemic subjects. The underlying HDL-C level raising mechanisms are not completely understood. Another target gene of PPAR $\alpha$ that might be involved in raising HDL-C levels is PLTP [56-58], which was up-regulated in dyslipidemic subjects (Figure 3). PLTP can modulate HDL-C size and composition $[59,60]$ by the transfer of phospholipids from TGrich lipoproteins to HDL-C particles [61]. However, in contrast to our results, incubation of Hep G2 cells with EPA, DHA or arachidonic acid resulted in a decreased expression of PLTP [62]. Similarly, results from animal trials were inconsistent. Both PLTP deficiency and PLTP overexpression resulted in a significant reduction of HDL-C levels in the circulation [63]. 


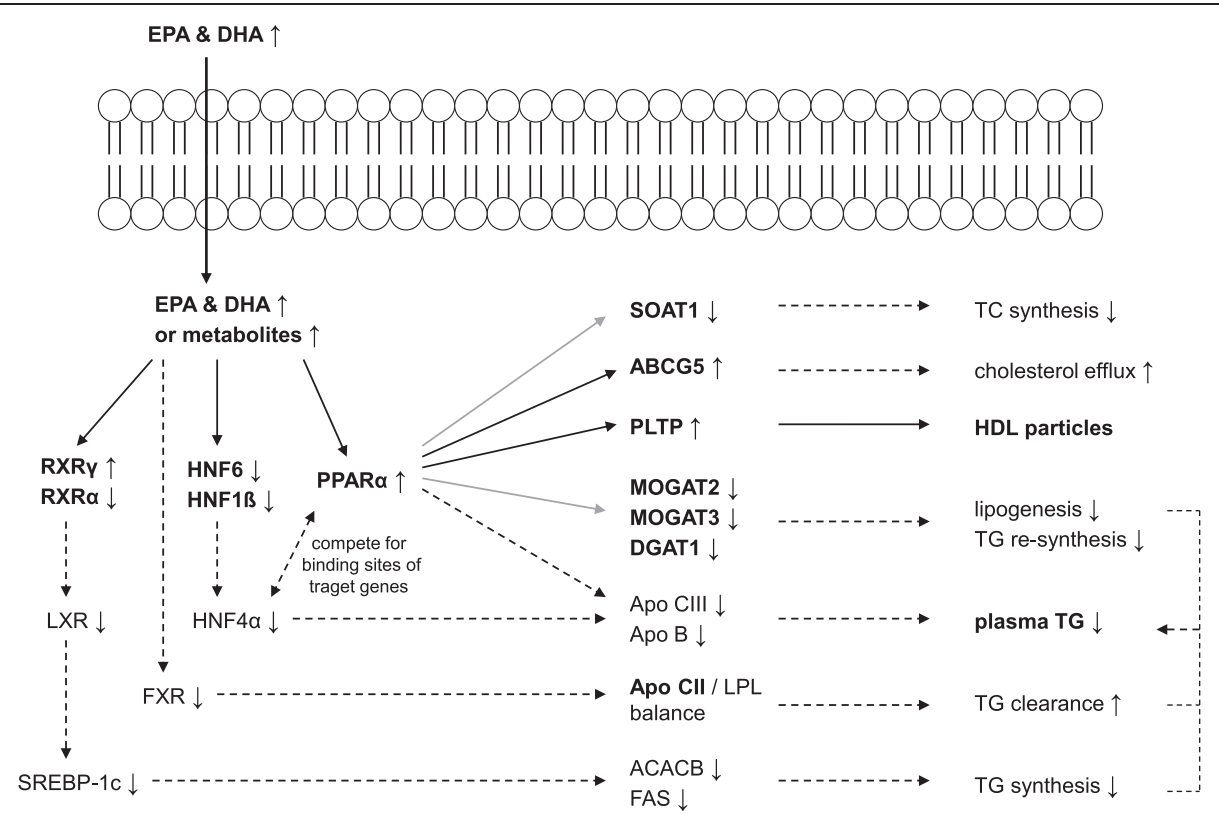

Figure 3 Transcript levels of target genes in normolipidemic and dyslipidemic men. Transcript levels of apolipoprotein CII (Apo CII) and low-density lipoprotein receptor (LDLR) was determined by qRT-PCR in normo- and dyslipidemic men before $\left(t_{0}\right)$ and after twelve weeks ( $\left.t_{12}\right)$ of fish oil supplementation. Pooled group samples were used in triplicates. Triplicates were averaged and corrected by two reference genes, glyceraldehyde-3-phosphate dehydrogenase (GAPDH) and ribosomal proteine S2 (RPS2). Corrected expressions were compared with baseline gene expression of normolipidemic subjects and relative expression changes are displayed.

Total cholesterol and LDL cholesterol metabolism

A well-known effect of FO supplementation is a slight increase of LDL-C levels after n-3 PUFA supplementation [5], which is most likely the result of an increased conversion of VLDL-C to LDL-C [13]. Although we observed a considerable increase in LDL-C levels in dyslipidemic subjects, the expression of several regulated genes in the same subjects indicate not only cholesterollowering, but also an enhancing effect (Figure 3). LDLR, which is expressed in nearly all cells, but predominantly in liver cells, transports cholesterol-rich lipoprotein particles, preferably LDL-C, via endocytosis into the cell, resulting in LDL-C clearance [64]. Even though high cholesterol concentrations inhibit the LDLR expression [65], LDLR mRNA levels in dyslipidemic subjects were two times higher compared to normolipidemic subjects. After FO supplementation, the LDLR expression was down-regulated in dyslipidemic subjects, which is in agreement with other studies [66]. The reduced LDLR expression suggests a diminished LDL-C clearance and could be another mechanism explaining the n-3 PUFAinduced rise in LDL-C levels.

In contrast, the regulation of two other factors points to a cholesterol-lowering effect. The half-transporters ABCG5 and ABCG8 play a pivotal role in the regulation of dietary cholesterol transport into the intestinal and biliary lumen for faecal excretion [67]. The upregulation of ABCG5 in dyslipidemic subjects might induce a pathway that results in increased cholesterol efflux. In agreement with our results, two animal studies revealed an increased hepatic ABCG5 and ABCG8 expression in mice after FO feeding [68,69]. The regulation might be triggered by PPARA, since PPAR $\alpha$ agonists caused an up-regulation of ABCG5 expression in hypercholesterolemic subjects [70].

Similarly, the down-regulation of SOAT1, observed in dyslipidemic subjects after FO supplementation, suggests a cholesterol-lowering effect. SOATs play important roles in cellular cholesterol homeostasis in various tissues [71]. Accordingly, a down-regulation of SOAT1 expression after n-3 PUFA treatment has been observed in human breast cancer cells [72].

\section{Limitations}

The study has a number of potential limitations. As already mentioned, it is critical to investigate the regulative effect of n-3 PUFAs on the expression of lipid metabolism-associated genes in whole blood cells instead of liver cells. However, the sampling of biopsies from the liver in this study was precluded for ethical and medical reasons. We similarly abstained from isolating lymphocytes or peripheral blood mononuclear cells (PBMCs), an approach which was chosen by two other groups investigating a similar question [73,74], since cell fractioning steps involve stress-induced alterations in gene expression profiles [75]. However, many lipid 
metabolism-associated genes are also expressed in nucleated blood cells: For example, PPAR $\alpha$ is expressed in monocytes, macrophages and lymphocytes [76,77], while HNF6 and DGAT were found to be expressed in PBMCs $[48,78]$. In addition, the pooling of RNA samples reduces inter-individual variation, enabling one to focus on the effects of FO supplementation on the population level in contrast to an individual level [79]. However, the approach of sample pooling provides several limitations, primarily the reduction of statistical power.

\section{Conclusion}

This pilot study suggests molecular pathways on how n-3 PUFAs affect lipid metabolism. Although the study is limited by the usage of whole blood cells obviating strong conclusions about lipid metabolism, several lipid metabolism-associated genes were shown to be regulated on a transcriptional level in dyslipidemic subjects, including transcription factors PPAR $\alpha, \mathrm{RXR} \alpha, \mathrm{RXR} \gamma$, HNF6, and HNF1ß, as well as other lipid regulators, MOGAT2, MOGAT3, DGAT1, Apo CII, PLTP, LDLR, ABCG5, and SOAT1. We assume that this transcriptional regulation will equally take place in cells of the liver or other tissues. Given this assumption, n-3 PUFAs activate several transcription factors resulting in the regulation of numerous target genes which, in turn, affect multiple lipid regulators. Accordingly, the results give indications for (1) decreased TG levels as a result of an enhanced VLDL catabolism and reduced VLDL production, as well as a decreased TG resynthesis in enterocytes and hepatocytes, while (2) increased HDL-C levels may be the result of an increased transfer of phospholipids from TG-rich lipoproteins to HDL-C particles. Finally, (3) LDL-C levels may be influenced in both directions: A decreased LDL-C clearance may result in rising LDL-C levels, on the one hand, while an increased cholesterol efflux and a reduced cholesteryl ester synthesis result in decreasing LDL-C levels, on the other hand. Future studies combining gene expression, metabolic markers and clinical end points need to clarify the significance of the hypothesized molecular mechanisms.

\footnotetext{
Abbreviations

ABCG5: ATP-binding cassette sub-family G member 5; Apo: Apolipoprotein; DGAT: Diacylglycerol O-acyltransferase; DHA: Docosahexaenoic acid; EPA: Eicosapentaenoic acid; FA: Fatty acid; FO: Fish oil; GAPDH: Glyceraldehyde-3-phosphate dehydrogenase; GCP: Good clinical practice; HDL-C: High-density lipoprotein cholesterol; HNF: Hepatic nuclear factor; LDL-C: Low-density lipoprotein cholesterol; LDLR: LDL receptor; LPL: Lipoprotein lipase; MOGAT: 2-acylglycerol O-acyltransferase; n-3 PUFA: Omega-3 polyunsaturated fatty acid; PPAR: Peroxisome proliferatoractivated receptor; PBMC: Peripheral blood mononuclear cells; PLTP: Phospholipid transfer protein; qRT-PCR: Quantitative real-time polymerase chain reaction; RPS2: Ribosomal protein S2; RXR: Retinoid X receptor; SOAT1: Sterol O-acyltransferase 1; SREBP: Sterol regulatory elementbinding protein; t: Time point; TC: Total cholesterol; TG: Triacylglycerol; VLDL: Very low-density lipoprotein.
}

\section{Competing interests}

The authors declare that they have no competing interests.

\section{Authors' contributions}

All authors have read and approved the final manuscript. SS was involved in the study, experimental design, data analysis, interpretation, and manuscript writing. The study was mainly performed by SS. FS was involved in the experimental design and informed advice. KOM was involved in the experimental design, data analysis and manuscript editing. JPS was involved in study design, data interpretation and manuscript writing. JW was involved in manuscript writing. The group leader of the Institute of Technical Chemistry, TS, was involved in the study design and manuscript editing. The group leader of the Institute of Food Science and Human Nutrition, AH, was involved in the study design and manuscript editing. Both JPS and AH were coordinators of the study.

\section{Acknowledgements}

The supply of the study supplements from Dr. Loges + Co. GmbH, Winsen, Germany, is gratefully acknowledged. Similarly, we thank Philip Saunders who proofread the manuscript. Most of all, we would like to thank the participants who contributed their time to this project.

This study was supported by the Federal Ministry of Education and Research, Germany.

\section{Author details}

${ }^{1}$ Institute of Food Science and Human Nutrition, Faculty of Natural Sciences at the Leibniz University of Hannover, Am Kleinen Felde 30, Hannover 30167, Germany. ${ }^{2}$ Institute of Technical Chemistry, Faculty of Natural Sciences at the Leibniz University of Hannover, Callinstr. 5, Hannover 30167, Germany.

Received: 11 September 2012 Accepted: 7 December 2012 Published: 14 December 2012

\section{References}

1. Harris WS: $n-3$ fatty acids and lipoproteins: comparison of results from human and animal studies. Lipids 1996, 3:243-252.

2. Harris WS: n-3 fatty acids and serum lipoproteins: human studies. Am J Clin Nutr 1997, 65:1645S-1654S.

3. Musa-Veloso K, Binns MA, Kocenas AC, Poon T, Elliot JA, Rice $H$, Oppedal-Olsen H, Lloyd H, Lemke S: Long-chain omega-3 fatty acids eicosapentaenoic acid and docosahexaenoic acid dose-dependently reduce fasting serum triglycerides. Nutr Rev 2010, 3:155-167.

4. Skulas-Ray AC, West SG, Davidson MH, Kris-Etherton PM: Omega-3 fatty acid concentrates in the treatment of moderate hypertriglyceridemia. Expert Opin Pharmacother 2008, 7:1237-1248.

5. Balk EM, Lichtenstein AH, Chung M, Kupelnick B, Chew P, Lau J: Effects of omega-3 fatty acids on serum markers of cardiovascular disease risk: a systematic review. Atherosclerosis 2006, 1:19-30.

6. Tremoli E, Eligini $S$, Colli $S$, Maderna $P$, Risè $P$, Pazzucconi $F$, Marangoni F, Sirtori CR, Galli C: n-3 fatty acid ethyl ester administration to healthy subjects and to hypertriglyceridemic patients reduces tissue factor activity in adherent monocytes. Arterioscler Thromb 1994, 10:1600-1608.

7. Kris-Etherton PM, Harris WS, Appel L: Fish consumption, fish oil, omega-3 fatty acids, and cardiovascular disease. Circulation 2002, 21:2747-2757.

8. Park Y, Harris WS: Omega-3 fatty acid supplementation accelerates chylomicron triglyceride clearance. J Lipid Res 2003, 3:455-463.

9. Schuchardt JP, Neubronner J, Kressel G, Merkel M, von Schacky C C, Hahn A: Moderate doses of EPA and DHA from re-esterified triacylglycerols but not from ethyl-esters lower fasting serum triacylglycerols in statintreated dyslipidemic subjects: Results from a six month randomized controlled trial. Prostaglandins Leukot Essent Fatty Acids 2011, 6:381-386.

10. Shearer GC, Savinova OV, Harris WS: Fish oil - How does it reduce plasma triglycerides? Biochim Biophys Acta 2012, 5:843-851.

11. Mori TA, Bao DQ, Burke V, Puddey IB, Watts GF, Beilin LJ: Dietary fish as a major component of a weight-loss diet: effect on serum lipids, glucose, and insulin metabolism in overweight hypertensive subjects. Am J Clin Nutr 1999, 5:817-825.

12. Mori TA, Burke V, Puddey IB, Watts GF, O'Neal DN, Best JD, Beilin LJ: Purified eicosapentaenoic and docosahexaenoic acids have differential effects on serum lipids and lipoproteins, LDL particle size, glucose, and insulin in mildly hyperlipidemic men. Am J Clin Nutr 2000, 5:1085-1094. 
13. Lu G, Windsor SL, Harris WS: Omega-3 fatty acids alter lipoprotein subfraction distributions and the in vitro conversion of very low density lipoproteins to low density lipoproteins. J Nutr Biochem 1999, 3:151-158.

14. Caputo M, Zirpoli H, Torino G, Tecce MF: Selective regulation of UGT1A1 and SREBP-1c mRNA expression by docosahexaenoic, eicosapentaenoic, and arachidonic acids. J Cell Physiol 2011, 1:187-193.

15. López-Soldado I, Avella M, Botham KM: Suppression of VLDL secretion by cultured hepatocytes incubated with chylomicron remnants enriched in $\mathrm{n}-3$ polyunsaturated fatty acids is regulated by hepatic nuclear factor4alpha. Biochim Biophys Acta 2009, 12:1181-1189.

16. Howell G, Deng X, Yellaturu C, Park EA, Wilcox HG, Raghow R, Elam MB: N-3 polyunsaturated fatty acids suppress insulin-induced SREBP-1C transcription via reduced trans-activating capacity of LXRalpha. Biochim Biophys Acta 2009, 12:1190-1196

17. de Urquiza AM, Liu S, Sjöberg M, Zetterström RH, Griffiths W, Sjövall J, Perlmann T: Docosahexaenoic acid, a ligand for the retinoid $\mathrm{X}$ receptor in mouse brain. Science 2000, 5499:2140-2144.

18. Zhao A, Yu J, Lew J, Huang L, Wright SD, Cui J: Polyunsaturated fatty acids are FXR ligands and differentially regulate expression of FXR targets. DNA Cell Biol 2004, 8:519-526.

19. Oyekan A: PPARs and their effects on the cardiovascular system. Clin Exp Hypertens 2011, 5:287-293.

20. Clarke SD, Gasperikova D, Nelson C, Lapillonne A, Heird WC: Fatty acid regulation of gene expression: a genomic explanation for the benefits of the mediterranean diet. Ann N Y Acad Sci 2002, 967:283-298.

21. Davidson $M H$ : Mechanisms for the hypotriglyceridemic effect of marine omega-3 fatty acids. Am J Cardiol 2006, 4A:27i-33i.

22. Jump DB, Thelen A, Mater M: Dietary polyunsaturated fatty acids and hepatic gene expression. Lipids 1999, 34:S209-S212.

23. Price PT, Nelson CM, Clarke SD: Omega-3 polyunsaturated fatty acid regulation of gene expression. Curr Opin Lipidol 2000, 1:3-7.

24. Vanden Heuvel JP: Cardiovascular disease-related genes and regulation by diet. Curr Atheroscler Rep 2009, 6:448-455.

25. Schmidt S, Stahl F, Mutz K, Scheper T, Hahn A, Schuchardt JP: Different gene expression profiles in normo- and dyslipidemic men after fish oil supplementation: results from a randomized controlled trial. Lipids Health Dis 2012, 1:105

26. Schmidt S, Stahl F, Mutz K, Scheper T, Hahn A, Schuchardt JP: Transcriptome-based identification of antioxidative gene expression after fish oil supplementation in normo- and dyslipidemic men. Nutri metabol 2012, 1:45.

27. Rozen S, Skaletsky H: Primer3 on the WWW for general users and for biologist programmers. Methods Mol Biol 2000, 132:365-386.

28. Vandesompele J, de Preter K, Pattyn F, Poppe B, van Roy N, de Paepe A, Speleman F: Accurate normalization of real-time quantitative RT-PCR data by geometric averaging of multiple internal control genes. Genome Biol 2002, 3. doi:10.1186/gb-2002-3-7-research0034. RESEARCH0034.

29. Forman BM, Chen J, Evans RM: Hypolipidemic drugs, polyunsaturated fatty acids, and eicosanoids are ligands for peroxisome proliferatoractivated receptors alpha and delta. Proc Natl Acad Sci USA 1997. 9:4312-4317.

30. Kliewer SA, Sundseth SS, Jones SA, Brown PJ, Wisely GB, Koble CS, Devchand P, Wahli W, Willson TM, Lenhard JM, Lehmann JM: Fatty acids and eicosanoids regulate gene expression through direct interactions with peroxisome proliferator-activated receptors alpha and gamma. Proc Natl Acad Sci USA 1997, 9:4318-4323.

31. Staels B, Dallongeville J, Auwerx J, Schoonjans K, Leitersdorf E, Fruchart JC: Mechanism of action of fibrates on lipid and lipoprotein metabolism. Circulation 1998, 19:2088-2093.

32. Jong MC, Hofker MH, Havekes LM: Role of ApoCs in lipoprotein metabolism: functional differences between ApoC1, ApoC2, and ApoC3. Arterioscler Thromb Vasc Biol 1999, 3:472-484.

33. Knott TJ, Rall SC, Innerarity TL, Jacobson SF, Urdea MS, Levy-Wilson B, Powell LM, Pease RJ, Eddy R, Nakai H: Human apolipoprotein B: structure of carboxyl-terminal domains, sites of gene expression, and chromosomal localization. Science 1985, 4721:37-43.

34. Wang H, Eckel RH: Lipoprotein lipase: from gene to obesity. Am J Physiol Endocrinol Metab 2009, 2:E271-E288.

35. Wang K, Holterman A: Pathophysiologic role of hepatocyte nuclear factor 6. Cell Signal 2012, 1:9-16.
36. Hatzis $P$, Talianidis I: Regulatory mechanisms controlling human hepatocyte nuclear factor 4alpha gene expression. Mol Cell Biol 2001, 21:7320-7330.

37. Ladias JA, Hadzopoulou-Cladaras M, Kardassis D, Cardot P, Cheng J, Zannis $\checkmark$, Cladaras C: Transcriptional regulation of human apolipoprotein genes ApoB, ApoCIII, and ApoAll by members of the steroid hormone receptor superfamily HNF-4, ARP-1, EAR-2, and EAR-3. J Biol Chem 1992, 22:15849-15860

38. Sladek FM: Orphan receptor HNF-4 and liver-specific gene expression. Receptor 1994, 1:64.

39. Hertz R, Magenheim J, Berman I, Bar-Tana J: Fatty acyl-CoA thioesters are ligands of hepatic nuclear factor-4alpha. Nature 1998, 6675:512-516.

40. Kei AA, Filippatos TD, Tsimihodimos V, Elisaf MS: A review of the role of apolipoprotein C-II in lipoprotein metabolism and cardiovascular disease. Metab Clin Exp 2012, doi:10.1016/j.metabol.2011.12.002.

41. Liu Y, Wang J, Zhang R, Zhang Y, Xu Q, Zhang J, Zhang Y, Zheng Z, Yu X, Jing H, Nosaka N, Kasai M, Aoyama T, Wu J, Xue C: A good response to oil with medium- and long-chain fatty acids in body fat and blood lipid profiles of male hypertriglyceridemic subjects. Asia Pac J Clin Nutr 2009, 3:351-358.

42. Sakurabayashi I, Saito Y, Kita T, Matsuzawa Y, Goto Y: Reference intervals for serum apolipoproteins A-I, A-II, B, C-II, C-III, and E in healthy Japanese determined with a commercial immunoturbidimetric assay and effects of sex, age, smoking, drinking, and Lp(a) level. Clin Chim Acta 2001, 1-2:87-95.

43. Zhang J, Wang C, Li L, Man Q, Meng L, Song P, Frøyland L, Du Z: Dietary inclusion of salmon, herring and pompano as oily fish reduces CVD risk markers in dyslipidaemic middle-aged and elderly Chinese women. Br J Nutr 2012, 6:1-11.

44. Hall AM, Kou K, Chen Z, Pietka TA, Kumar M, Korenblat KM, Lee K, Ahn K, Fabbrini E, Klein S, Goodwin B, Finck BN: Evidence for regulated monoacylglycerol acyltransferase expression and activity in human liver. $J$ Lipid Res 2012, 5:990-999.

45. Cheng D, Nelson TC, Chen J, Walker SG, Wardwell-Swanson J, Meegalla R, Taub R, Billheimer JT, Ramaker M, Feder JN: Identification of acyl coenzyme A:monoacylglycerol acyltransferase 3, an intestinal specific enzyme implicated in dietary fat absorption. J Biol Chem 2003, 16:13611-13614.

46. Hiramine Y, Tanabe T: Characterization of acyl-coenzyme A:diacylglycerol acyltransferase (DGAT) enzyme of human small intestine. J Physiol Biochem 2011, 2:259-264.

47. Yen CE, Farese RV: MGAT2, a monoacylglycerol acyltransferase expressed in the small intestine. J Biol Chem 2003, 20:18532-18537.

48. Cases S, Smith SJ, Zheng YW, Myers HM, Lear SR, Sande E, Novak S, Collins C, Welch CB, Lusis AJ, Erickson SK, Farese RV: Identification of a gene encoding an acyl CoA:diacylglycerol acyltransferase, a key enzyme in triacylglycerol synthesis. Proc Natl Acad Sci USA 1998, 22:13018-13023.

49. Yen CE, Cheong M, Grueter C, Zhou P, Moriwaki J, Wong JS, Hubbard B, Marmor S, Farese RV: Deficiency of the intestinal enzyme acyl CoA: monoacylglycerol acyltransferase-2 protects mice from metabolic disorders induced by high-fat feeding. Nat Med 2009, 4:442-446.

50. Smith SJ, Cases S, Jensen DR, Chen HC, Sande E, Tow B, Sanan DA, Raber J, Eckel $\mathrm{RH}$, Farese RV: Obesity resistance and multiple mechanisms of triglyceride synthesis in mice lacking Dgat. Nat Genet 2000, 1:87-90.

51. Buhman KK, Smith SJ, Stone SJ, Repa JJ, Wong JS, Knapp FF, Burri BJ, Hamilton RL, Abumrad NA, Farese RV: DGAT1 is not essential for intestinal triacylglycerol absorption or chylomicron synthesis. J Biol Chem 2002, 28:25474-25479.

52. Berge RK, Madsen L, Vaagenes H, Tronstad KJ, Göttlicher M, Rustan AC: In contrast with docosahexaenoic acid, eicosapentaenoic acid and hypolipidaemic derivatives decrease hepatic synthesis and secretion of triacylglycerol by decreased diacylglycerol acyltransferase activity and stimulation of fatty acid oxidation. Biochem J 1999, 343(Pt 1):191-197.

53. van Greevenbroek MM, de Bruin TW: Chylomicron synthesis by intestinal cells in vitro and in vivo. Atherosclerosis 1998, 1:S9-S16.

54. Sakai N, Uchida $Y$, Ohashi $K$, Hibuse $T$, Saika $Y$, Tomari $Y$, Kihara $S$, Hiraoka $H$, Nakamura T, Ito S, Yamashita S, Matsuzawa Y: Measurement of fasting serum apoB-48 levels in normolipidemic and hyperlipidemic subjects by ELISA. J Lipid Res 2003, 6:1256-1262.

55. Kinoshita M, Ohnishi H, Maeda T, Yoshimura N, Takeoka Y, Yasuda D, Kusano J, Mashimo Y, Saito S, Shimamoto K, Teramoto T: Increased serum 
apolipoprotein B48 concentration in patients with metabolic syndrome. J Atheroscler Thromb 2009, 4:517-522.

56. Bouly M, Masson D, Gross B, Jiang XC, Fievet C, Castro G, Tall AR, Fruchart $J$ C, Staels B, Lagrost L, Luc G: Induction of the phospholipid transfer protein gene accounts for the high density lipoprotein enlargement in mice treated with fenofibrate. J Biol Chem 2001, 28:25841-25847.

57. Lemay DG, Hwang DH: Genome-wide identification of peroxisome proliferator response elements using integrated computational genomics. J Lipid Res 2006, 7:1583-1587.

58. Tu AY, Albers JJ: DNA sequences responsible for reduced promoter activity of human phospholipid transfer protein by fibrate. Biochem Biophys Res Commun 1999, 3:802-807.

59. Jauhiainen M, Metso J, Pahlman R, Blomqvist S, van Tol A, Ehnholm C: Human plasma phospholipid transfer protein causes high density lipoprotein conversion. J Biol Chem 1993, 6:4032-4036.

60. Settasatian N, Duong M, Curtiss LK, Ehnholm C, Jauhiainen M, Huuskonen J, Rye KA: The mechanism of the remodeling of high density lipoproteins by phospholipid transfer protein. J Biol Chem 2001, 29:26898-26905.

61. Tall AR, Krumholz S, Olivecrona T, Deckelbaum RJ: Plasma phospholipid transfer protein enhances transfer and exchange of phospholipids between very low density lipoproteins and high density lipoproteins during lipolysis. J Lipid Res 1985, 7:842-851.

62. Kuang $Y$, Eric Paulson $\mathrm{K}$, Lichtenstein AH, Lamon-Fava S: Regulation of the expression of key genes involved in HDL metabolism by unsaturated fatty acids. Br J Nutr 2012, 6:1-9.

63. Yazdanyar A, Yeang C, Jiang X: Role of phospholipid transfer protein in high-density lipoprotein- mediated reverse cholesterol transport. Curr Atheroscler Rep 2011, 3:242-248.

64. Brown MS, Goldstein JL: A receptor-mediated pathway for cholesterol homeostasis. Science 1986, 4746:34-47.

65. Goldstein JL, Brown MS: Molecular medicine. The cholesterol quartet. Science 2001, 5520:1310-1312.

66. Dawson K, Zhao L, Adkins Y, Vemuri M, Rodriguez RL, Gregg JP, Kelley DS, Hwang DH: Modulation of blood cell gene expression by DHA supplementation in hypertriglyceridemic men. J Nutr Biochem 2011, 6:616-621.

67. Yu L, Hammer RE, Li-Hawkins J, von Bergmann K, Lutjohann D, Cohen JC, Hobbs HH: Disruption of Abcg5 and Abcg8 in mice reveals their crucial role in biliary cholesterol secretion. Proc Natl Acad Sci USA 2002, 25:16237-16242.

68. Kamisako T, Tanaka Y, Ikeda T, Yamamoto K, Ogawa H: Dietary fish oil regulates gene expression of cholesterol and bile acid transporters in mice. Hepatol Res 2012, 3:321-326.

69. Nishimoto T, Pellizzon MA, Aihara M, Stylianou IM, Billheimer JT, Rothblat G, Rader DJ: Fish oil promotes macrophage reverse cholesterol transport in mice. Arterioscler Thromb Vasc Biol 2009, 10:1502-1508.

70. Roglans N, Vázquez-Carrera M, Alegret M, Novell F, Zambón D, Ros E, Laguna JC, Sánchez RM: Fibrates modify the expression of key factors involved in bile-acid synthesis and biliary-lipid secretion in gallstone patients. Eur J Clin Pharmacol 2004, 12:855-861.

71. Chang T, Li B, Chang CCY, Urano Y: Acyl-coenzyme A:cholesterol acyltransferases. Am J Physiol Endocrinol Metab 2009, 1:E1-E9.

72. Hammamieh R, Chakraborty N, Miller S, Waddy E, Barmada M, Das R, Peel SA, Day AA, Jett M: Differential effects of omega- 3 and omega- 6 Fatty acids on gene expression in breast cancer cells. Breast Cancer Res Treat 2007, 1:7-16.

73. Bouwens M, van de Rest O, Dellschaft N, Bromhaar MG, de Groot LCPGM, Geleijnse JM, Müller M, Afman LA: Fish-oil supplementation induces antiinflammatory gene expression profiles in human blood mononuclear cells. Am J Clin Nutr 2009, 2:415-424.

74. Gorjão R, Verlengia R, de Lima TM, Soriano FG, Boaventura MFC, Kanunfre CC, Peres CM, Sampaio SC, Otton R, Folador A, Martins EF, Curi TCP, Portiolli EP, Newsholme P, Curi R: Effect of docosahexaenoic acid-rich fish oil supplementation on human leukocyte function. Clin Nutr 2006, 6:923-938.

75. Vartanian K, Slottke R, Johnstone T, Casale A, Planck SR, Choi D, Smith JR, Rosenbaum JT, Harrington CA: Gene expression profiling of whole blood: comparison of target preparation methods for accurate and reproducible microarray analysis. BMC Genomics 2009, 10:2.

76. Chinetti G, Griglio S, Antonucci M, Torra IP, Delerive P, Majd Z, Fruchart JC, Chapman J, Najib J, Staels B: Activation of proliferator-activated receptors alpha and gamma induces apoptosis of human monocyte-derived macrophages. J Biol Chem 1998, 40:25573-25580.

77. Mandard S, Müller M, Kersten S: Peroxisome proliferator-activated receptor alpha target genes. Cell Mol Life Sci 2004, 4:393-416.

78. Zhao Y, Huang Z, Lazzarini P, Wang Y, Di A, Chen M: A unique human blood-derived cell population displays high potential for producing insulin. Biochem Biophys Res Commun 2007, 1:205-211.

79. Kendziorski C, Irizarry RA, Chen K, Haag JD, Gould MN: On the utility of pooling biological samples in microarray experiments. Proc Natl Acad SCI USA 2005, 12:4252-4257.

doi:10.1186/1476-511X-11-172

Cite this article as: Schmidt et al:: Regulation of lipid metabolism-related gene expression in whole blood cells of normo- and dyslipidemic men after fish oil supplementation. Lipids in Health and Disease 2012 11:172.

\section{Submit your next manuscript to BioMed Central and take full advantage of:}

- Convenient online submission

- Thorough peer review

- No space constraints or color figure charges

- Immediate publication on acceptance

- Inclusion in PubMed, CAS, Scopus and Google Scholar

- Research which is freely available for redistribution 